\title{
IS KIERKEGAARD A “VIRTUE ETHICIST”?
}

\author{
Robert C. Roberts
}

\begin{abstract}
Several readers of Kierkegaard have proposed that his works are a good source for contemporary investigations of virtues, especially theistic and Christian ones. Sylvia Walsh has recently offered several arguments to cast doubt on the thesis that Kierkegaard can be profitably read as a "virtue ethicist." Examination of her arguments helps to clarify what virtues, as excellent traits of human character, can be in a moral outlook that ascribes deep sin and moral helplessness to human beings and their existence and salvation entirely to God's grace. The examination also clarifies the relationship between virtues and character and between the practices of virtue ethics and character ethics. Such clarification also may provide a bridge of communication between Kierkegaard scholarship and scholars of virtue ethics beyond the theistic communities. In particular, I'll argue that a character ethics that is not a virtue ethics would be suboptimal as an aid to the formation of Christian wisdom and sanctification. Kierkegaard's character ethics is a virtue ethics.
\end{abstract}

\section{Introduction}

In a rich and informative recent book, Kierkegaard and Religion, Sylvia Walsh argues that Kierkegaard should not be read as a kind of "virtue ethicist." She is responding to a small band of Kierkegaard interpreters who, in diverse ways, see continuities between Kierkegaard and virtue ethics. They find support for this reading in his comments about character, upbringing, upbuilding, inwardness, becoming a self, consolidating personality, and being an individual; and in his detailed expositions of moral and spiritual qualities such as courage, bold confidence, simplicity, faith, meekness, truth, earnestness, love, patience, humility, forgiveness, honesty, hope, gratitude, and mercifulness. Kierkegaard seems to them to be practicing a kind of "virtue ethics," in some ways continuous with ancient Greek ethics and its revival in more recent philosophical moral psychology. ${ }^{1}$ This paper is an assessment of Walsh's assessment of this claim which will, I hope, clarify what it is or might be to advocate the language of virtue in

\footnotetext{
${ }^{1}$ Walsh cites work by Gregory Beabout, Andrew Burgess, Randall Colton, John Davenport, David Gouwens, David Humbert, Jason Mahn, Robert Roberts, Anthony Rudd, Mark Tietjen, and Claudia Welz.
} 
Christian ethical thought. I will state Walsh's arguments and respond to them. The result should be to clarify both a Christian concept of virtue and Kierkegaard's relationship to "virtue ethics."

In retrospect of her arguments Walsh concludes,

A close examination of key texts and passages from Kierkegaard's writings does not support an interpretation of him as a virtue ethicist in continuity with the classical and medieval virtue traditions and the contemporary revival of virtue ethics. The fact that Kierkegaard does not employ the language of virtue in defining character and the spiritual qualities that constitute it also indicates that, in agreement with some empirical studies, he does not equate character with virtue, which in his view is associated with sagacity [worldly cunning], the complacent social morality of Christendom, and selfish or "being for oneself" qualities acquired and/or perfected by human agency. The spiritual qualities that distinguish ethical-religious and Christian character, by contrast, are given by God, appropriated in freedom, and possessed unselfishly. ${ }^{2}$

Nevertheless, Walsh notes that Kierkegaard's intense concern with character, personality, inwardness, being an individual, becoming a self, and subjectivity suggests that he should be called a character ethicist, and she affirms that his writings are saturated with discussions of specific "spiritual qualities" - distinct aspects of good character. I will examine her reasons for rejecting the label "virtue ethicist" and her understanding of the difference between virtue and character.

I now state the theses of this paper about virtues inspired by Kierkegaard's thought. Christian virtues are not the same traits as pagan virtues. Christian virtues are not ways of achieving merit or justification before God. They are not "perfections" in the absolute sense. They are not acquired without divine help. Christian virtues, while benefiting their possessor, are not solely for the benefit of their possessor. They are not "habits" in the ordinary sense of the word. They are infused with a "negative" character that reflects the pervasiveness of sin in human life. Christian virtues are products of free choice and striving. They are achievable to some extent and are God's achievement in us. They are traits of character. Though Kierkegaard uses the word "virtue" little-far less than he uses "character," "inwardness," "the single individual," and other virtue-like terms - the specific character traits that he explores at length are virtues, given the exclusions and qualifications just summarized. That is, in the most encompassing definition, virtues are just good traits of character. And we need a broad, liberal definition of "virtue," because virtue concepts are embedded in views of the world and of God and of human nature, and thus can vary as widely in their particular features as such philosophies, religions, and worldviews differ from one another. Comparing the features of Christian virtues listed in this paragraph, gleaned

${ }^{2}$ Walsh, Kierkegaard and Religion, 176. 
from Kierkegaard's thought, with their counterparts in non-Christian outlooks illustrates this point.

In the contemporary discussion, "virtue ethics" is a broad term used to refer to a variety of quite different constructs that have some reference to virtue concepts. ${ }^{3}$ Particularly pertinent to the study of Kierkegaard is a difference that Walsh does not clarify when she says that Kierkegaard is not a virtue ethicist in the sense of "the contemporary revival of virtue ethics." One strand of contemporary virtue ethics sees it as an ethical theory on analogy, and perhaps in competition with, modern ethical theories such as Kantian deontology and various consequentialisms. ${ }^{4}$ Clearly, Kierkegaard is not a virtue ethicist in this sense. His goal is not to come up with an ethical theory, but to contribute to his readership's transformation of character. His strategy in this character-upbuilding project characteristically involves focusing on and ruminating about specific qualities of character-faith, love, patience, humility, gratitude, and all the rest. His focus on these distinct but interrelated spiritual qualities, which are traditionally called "virtues," gives his writing much of the communicating power for which it is known. In this way he is much less like the philosophers of "the contemporary revival of virtue ethics" than he is like the ancient ethicists, Socrates, Plato, Aristotle, and the Hellenistic philosophers, for whom the purpose of philosophy was to make human beings wise, complete, mature, and fully human. ${ }^{5}$

\section{Some References to Virtues in Kierkegaard's Writings}

Walsh correctly observes that after Eighteen Upbuilding Discourses, the last of which were published in 1844, Kierkegaard does not much use the word "virtue" in a directly commendatory way. But she makes him out to be speaking critically of virtue where in fact he isn't. Here is a passage in which she apparently misses the irony in his use of "virtue." She writes,

In [a journal] entry from 1847 [Kierkegaard] likens "patience, faith, humility, etc. in short, all the Christian virtues" to "heroism in peacetime" in which people play at religion just as they play at war. ${ }^{6}$

On this reading the Christian virtues are not ethically serious spiritual qualities. But if we look at the journal entry itself, we see that the references to the virtues are ironic. Kierkegaard writes,

Patience, faith, humility, etc., in short, all the Christian virtues in non-actual dangers (for example, when a person shirks making the right decisions, refuses to take the shower bath of actuality so that he is actually scoffed at, is actually destitute, is actually hated by the world, etc.) are like heroism

${ }^{3}$ See Roberts, "Varieties of Virtue Ethics."

${ }^{4}$ Hursthouse, On Virtue Ethics; Slote, Morals from Motives; Watson, "The Primacy of Character." For critique, see Roberts, Emotions in the Moral Life, chapter 1.

${ }^{5}$ See Hadot, What Is Ancient Philosophy?

${ }^{6}$ Walsh, Kierkegaard and Religion, 98. 
in peacetime. It is as if a soldier on the drill ground in a peaceful military exercise to capture a peewit-house assumed a martial air like that of Daniel Rantzau in battle. What is comical about it is the martial air-and the danger is pure nonsense, make-believe, a stage setting. Children play soldier, in peacetime men play war, and most men play at religion. ${ }^{7}$

Kierkegaard is using the expression "Christian virtues," not for the real thing, but for simulacra thereof, or what some people refer to as Christian virtues. His point is not that patience, faith, and humility are as bogus as a martial air adopted while playing war-games in peacetime, but that what people call patience, faith, and humility in Christendom, where everybody is a sort of Christian and nobody gets persecuted for endorsing Christianity, are like heroism in peacetime. Kierkegaard's criticism of such self-deceiving simulacra implies the very opposite: that real Christian virtues fit a person for reality in a way analogous to heroism in time of war.

Note that to use "virtue" ironically in reference to pseudo-excellences is to presuppose that in real or non-ironical references to virtue, virtue is a genuine excellence. These non-ironical meanings of the word shadow the ironic ones and are necessary to their irony. To say ironically that Donald Trump is a wise man is not to put down wisdom (that wouldn't be an ironical reference), but to put down Trump. When Socrates tells Euthyphro, ironically, that he wants Euthyphro to be his teacher, he isn't objecting to teachers, but putting Euthyphro in his place as a fake.

Walsh also quotes the Concluding Unscientific Postscript:

if it is a sorry error literally to want to be like God through virtue and holiness instead of becoming more and more humble, then it is all the more ludicrous to want to be that in consideration of one's being an unusually brilliant mind, because virtue and purity are indeed essentially related to the nature of God, but the second stipulation makes God himself ridiculous as the tertium comparationis [third element in a comparison, a standard]. ${ }^{8}$

Here Johannes Climacus is criticizing vain efforts to be like God through virtue and holiness, but not rejecting virtue and holiness; indeed, he is, after all, commending "becoming more and more humble" (and humility is one of the Christian virtues). Then he warns against thinking that you can have virtue and purity by having a brilliant mind, because God has these attributes and God has a brilliant mind! Positively he would be saying that human virtue and holiness falls infinitely short of God's glory (though it is "essentially related to the nature of God") and that human virtue and purity differs categorically from having a brilliant mind. These are points that a "virtue ethicist" after a Kierkegaardian or Protestant stamp will applaud.

Walsh notes that

${ }^{7}$ Kierkegaard, Journals and Papers, 1:941 (from 1847).

${ }^{8}$ Kierkegaard, Concluding Unscientific Postscript, 565, quoted in Walsh, Kierkegaard and Religion, 84. 
As Vigilius [Haufniensis] sees it, "all ancient ethics was based on the presupposition that virtue can be realized," whereas the Christian category of sin "lies entirely beyond its reach" as the concept upon which ethics is shipwrecked, suggesting that virtue is not attainable. ${ }^{9}$

Whether we are talking about Christian virtues or the virtues of "ancient ethics," it will be true that the category of sin "lies entirely beyond [their] reach" as remedies for sin. But the Christian virtues do take into consideration the category of sin; they presuppose it. For example, faith as belief and trust in the atonement of Christ obviously depends on an awareness of sin - the need for Christ's atonement. (More on this in a moment.)

Are faith, love, gratitude, and humility unattainable? Perfect or absolutely flawless faith and love and gratitude are unattainable, in Kierkegaard's view. To note this is just to note a general feature of Christian virtues: that only Christ perfectly exemplifies them. To assume they are not attainable to any extent at all would be to vitiate much of Kierkegaard's missionary work in Christendom. A Christian virtue ethics must allow that perfection in the Christian virtues can be only approximated in this life.

Kierkegaard eschews the great and heroic virtues of paganism in the following passage of his journal:

One can say that [Christiani]ty absolutely did not come into the world in order to develop these great virtues in the individual-on the contrary, the great virtues and the heroic were precisely what were prominent in paganism. But then the situation was in fact that precisely because the ideal $\kappa \alpha \tau^{\prime} \varepsilon \xi o \chi \eta \dot{~[p a r ~ e x c e l l e n c e] ~ w a s ~ u n k n o w n ~ t o ~ p a g a n i s m, ~ t h e ~ i n d i v i d u a l ~ w a s ~}$ given occasion to imagine that he himself could almost become the ideal and take pride in it, so the contrast came to be between these heroes and all other hum[an] beings, who were more or less idiots. Then the true ideal revealed itself. The true ideal reveals that everyone has need of grace, humbling everyone. Differences built upon selfishness cannot hold-because confronted with the ideal, the strongest needs grace just as much as the weakest. And in a certain sublime sense the ideal transforms into a jest all differences between one hum[an] being and another with respect to perfection. Thus Christianity did not come in order to develop these heroic virtues in the individual, but to remove selfishness and to set forth love: "Let us love one another." Less time and diligence is used in perfecting oneself up to a certain maximum - which can so easily be a sort of selfishness - than in working for others. $^{10}$

Those who had the "great virtues" of paganism often or characteristically used them, Kierkegaard thinks, to establish their superiority over their neighbors, "who were more or less idiots." Thus these "virtues" came equipped with a vicious selfish invidiousness, ${ }^{11}$ perhaps based on the idea that they were achievements attributable to their possessors' excellence

\footnotetext{
${ }^{9}$ Walsh, Kierkegaard and Religion, 84, citing Kierkegaard, Concept of Anxiety, 17, 19. 97.

${ }^{10}$ Kierkegaard, Journals and Papers, 1:991 (1851), quoted at Walsh, Kierkegaard and Religion,

${ }^{11}$ For confirmation, see Aristotle, Nicomachean Ethics, book 4, chapter 3.
} 
of choices. But the character ideal was wrong. When Christ, who really had the virtues, appeared, the effect among those who understood was to humble everyone and to show that any difference of excellence between one person and another was a joke (the laughter expresses humility, but with the sadness of contrition and compassion). The aim was not to be admired as better than one's neighbor, but to be as much like Christ as possible (to love the neighbor), and that was a task for a lifetime. ${ }^{12}$ Kierkegaard spent his entire work life in the effort to build up the church, to build up individuals, and to build them up in faith, hope, love, patience, humility, forgivingness, bold confidence, gratitude, simplicity, and other positive personal qualities that follow as imperatives from the gospel of grace preached to sinful people who are by nature a synthesis of freedom and "necessity."

\section{Sagacity and Virtue}

Walsh argues that, even within the Eighteen Upbuilding Discourses, where he does use "virtue" a few times in a commendatory way, Kierkegaard is ambivalent toward virtue, because on the one hand "he commends the beautiful virtue of a conciliatory spirit and suggests that it cannot be attained by being sagacious" and on the other he "associates virtue negatively with sagacity."13 Usually Kierkegaard uses "sagacity" (Kloghed) to mean something like worldly cunning or devious cleverness. But sometimes he uses the word neutrally to mean good at figuring out how to get from a to $b$. He contrasts a dutifully resolute person "who has understood what the highest is but is also willing to pay everything to buy it" with a sagacious person, who in a worldly manner buys at a high price only after "reckoning the conditions ${ }^{\prime 14}$ that seem to him to make the high price still a good bargain. Here is the passage that Walsh regards as evidence that Kierkegaard associates virtue with worldly cunning or devious cleverness:

It is true and always will be true that virtue is the highest sagacity. It is also certain that the sensate person is eager to be sagacious and aspires to sagacity, but even if someone, in order to win him, were to expound this, he still would never win him to virtue; if that is to happen, the sensate person's conception of sagacity would first have to be completely altered. ${ }^{15}$

If we take sagacity to be the capacity to discern the way to one's best interest, then true sagacity - we might call it wisdom-for Kierkegaard will be something like the ability to discern the way to one's eternal happiness. The sensate person, as sensate, being locked into a misconception of what

\footnotetext{
${ }^{12}$ If we think of heroism as the ability to maintain one's integrity against the erosions of crowd-morality, heroism is clearly a good thing in Kierkegaard's judgment. I am grateful to an anonymous referee for alerting me to this.

${ }^{13}$ Walsh, Kierkegaard and Religion, 86.

${ }^{14}$ Kierkegaard, Eighteen Upbuilding Discourses, 379.

${ }^{15}$ Walsh, Kierkegaard and Religion, 84 citing Kierkegaard, Eighteen Upbuilding Discourses, 380.
} 
is in his own best interest, will be impervious to efforts to win him to virtue by showing him what makes for his eternal happiness. If he is to be won over to virtue, he must change his conception of what is in his own best interest - which is to say that he must forsake his sensate view of the world. The person who has true sagacity will also understand the ways a sensate sagacity still has some hold on her, but will use her knowledge of its patterns of reasoning to put herself on guard against them in the interest of the telos of the higher sagacity. "Only that sagacity is true that helps a person to make every sacrifice in order to will the good in truth."16 Despite this last quotation, Walsh seems not to notice that sagacity comes in at least two types: true sagacity and sensate sagacity. She seems to assume that "sagacity" must mean devious cleverness, and therefore to say that "virtue is the highest sagacity" must be to treat it "negatively." But this is not the most natural reading of the passage.

\section{Increased Awareness of Ethical Deficiency and the Christian Inverse Dialectic}

In the Concluding Unscientific Postscript Kierkegaard's pseudonym Johannes Climacus presents at length an account of what happens when a person seriously undertakes to relate "absolutely to the absolute and relatively to all relative ends." In more ordinary words, this is an effort to obey God unconditionally, to take with absolute seriousness the first commandment, and to treat no other goals as even in competition with one's devotion to God. Climacus conducts the reader through three successively deepening stages of "existential pathos"17: the initial expression is the desire to be related to God in perfect devotion; the essential expression is the suffering of frustration of this desire; and the decisive expression is the guilt in which the person finds himself mired and unable to extricate himself. This is the ideal preparation for life in Christ, in which one receives the God-relationship as a gift, entirely unmerited and as acquired independently of one's own tired agency. Walsh thinks this story separates Kierkegaard from all virtue ethics.
Another reason why it is problematic to call Kierkegaard a virtue ethicist is suggested by the process of ethical-religious development in Concluding Unscientific Postscript (1846), where human striving culminates not in the achievement of a virtuous personality but just the opposite, namely in an increasing realization of our inability to bring our lives into conformity with the good. ${ }^{18}$

An awareness of your own failings, if veridical, certainly indicates that you haven't arrived at perfect virtue. But the opposite of a virtuous personality is not an awareness of your failings, but a vicious personality. Part of a

\footnotetext{
${ }^{16}$ Kierkegaard, Upbuilding Discourses in Various Spirits, 94 cited by Walsh, Kierkegaard and Religion, 84 .

${ }^{17}$ Kierkegaard, Concluding Unscientific Postscript, 387-555.

${ }^{18}$ Walsh, Kierkegaard and Religion, 91.
} 
person's viciousness may be his obliviousness of his vice, ${ }^{19}$ and the awareness of your failings may be virtuous. Indeed, that's the way it seems to go in Climacus's account: the moral progress is the ability to recognize how far you are from perfection. Contrition is not an Aristotelian virtue, but it is a Christian virtue, one that is intimately related to the virtue of faith and that expresses Christian wisdom and humility. Here we encounter what Kierkegaard calls Christianity's "inverse dialectic."

Christianity's dialectic is inverse in comparison with the dialectic of any ethical outlook according to which you make moral progress by a direct path like the following: You have a moral goal (say, you want to be more generous) and you set out to become more generous by acting more generously, by setting your mind on the beauty of generosity, by contemplating the potential good you will do by your generosity, and so forth. You may have setbacks along the way, but if you soldier on you will prevail. If this kind of account is the most basic outline for progress in Christianity, then Christianity's dialectic is just like Aristotle's, a "direct" dialectic. To think this is right, thinks Kierkegaard, is to distort and superficialize Christianity. It is to underrate the difficulty that is signaled by the first commandment. When we seek, by a direct route, to obey the first commandment, or to follow Jesus's instructions to the letter, we find ourselves spiritually knocked back on our heels. But if we are faithful, we don't give up the fight, even though we become increasingly aware of our inability to achieve the goal on our own. We become increasingly grateful for God's grace in Christ and the help of the Holy Spirit in our spiritual struggles. (Gratitude is another Christian virtue.)

Walsh thinks the inverse dialectic of Christianity in Kierkegaard's thought is a reason for thinking he isn't a virtue ethicist:

As inverse dialectic applies to a human being's relation to God, therefore, we come close to God only in worship, and closest of all in bowing down at the foot of the altar, where in silent confession of our sinfulness and nothingness before God we seek forgiveness for our sins and reconciliation with God in and through Christ's atonement for sin. A heightening of the God-relationship in Christianity is thus expressed inversely by a lowering of oneself in which one goes forward by going backward in the development of a deepening sense of one's unlikeness to and infinite distance from the divine rather than a direct likeness and closeness to it. ${ }^{20}$

We might divide the spiritual qualities that Kierkegaard seeks to build up in his reader into three groups: 1 ) the ones that directly express the inverse dialectic-qualities like self-control, penitence, humility, and honesty about our own shortcomings; 2) ones that presuppose the shortcomings of others-forgiveness, forbearance, and compassion; and 3) others that incorporate the inverse dialectic without expressing it directly, such as faith, love, hope, bold confidence, obedience, and truth. All the Christian

\footnotetext{
${ }^{19}$ See Aristotle, Ethics, book 7, chapter 8.

${ }^{20}$ Walsh, Kierkegaard and Religion, 130.
} 
spiritual qualities partake in some way of the inverse dialectic. It is interesting to note that none of the virtues listed here is a virtue in Aristotle's ethics. Walsh doesn't deny that Kierkegaard seeks to build up good spiritual qualities. She calls them traits of character. But she thinks they aren't virtues because they are permeated by the inverse dialectic. But why not just say, with a good portion of the Christian tradition, that the Christian virtues are characterized by an inverse dialectic, thus differing in this fundamental respect from virtues in other moral traditions? They are good qualities of character, so they are virtues.

A person who started out with naïve optimism of success on the project of relating absolutely to the absolute and relatively to all relative ends will no doubt at certain points in her journey feel farther from her goal than she was at the start. But it seems reasonable to me to say that she is closer to an actual eternal happiness, even though she feels that she is farther away. But if she does take her initial optimism as the standard, she is mistaken about what an eternal happiness actually is; and part of the process of edification is that she outgrows the false conception. The suffering is actually progress because it is eroding the striver's false conception of self and the good. Kierkegaard seems to think that it's part of Christian wisdom to realize that Christianity has this inverse dialectic. Knowing this will help the striver avoid the twin pitfalls of unrealistic optimism and despair.

\section{Human and Divine Agency in Virtue Acquisition: The Question of Merit}

Some people may reason as follows: A virtue is a trait for which the possessor gets credit. You don't get credit for being six feet tall, even though it's a good trait to have (it helps you reach high shelves); but you do get credit for your honesty, as long as you came by it honestly. If you got it by having a neurological operation or by taking a drug, then you didn't come by it honestly, and don't get credit for it, and it's not a virtue. Walsh seems to have people like this in mind when she says,

Far from suggesting that we can attain the good on our own as claimed in classical $^{21}$ and some contemporary forms of virtue ethics, Kierkegaard emphasizes divine agency and a total reliance on the grace of God for the gift of spiritual goods, which are perfect in themselves. But constant activity on our part as unworthy servants and co-workers of God in giving them expression in our daily lives is also required inasmuch as for Kierkegaard "everything spiritual is appropriated only in freedom."22

Christians believe we can do nothing without God's help, including the acquisition of spiritual qualities, but this is not the same as saying we can do nothing at all, or that we can do nothing to acquire spiritual qualities. As

\footnotetext{
${ }^{21}$ Plato and Aristotle didn't think an individual could acquire the virtues entirely on his or her own. Both thought that virtue acquisition required the help of other persons in the form of a well-constituted community, though neither thought belonging to such a community sufficient for the formation of virtues. That requires individual buy-in. 60.

${ }^{22}$ Walsh, Kierkegaard and Religion, 91, citing Kierkegaard, Eighteen Upbuilding Discourses,
} 
Walsh emphasizes, a virtue ethics that holds that we can become virtuous without any help from God is not Christian. But this denial is not to say that no virtue ethics at all is Christian. A Christian virtue ethics will stress God's role in our acquisition of the virtues, but it will also allow for the free co-operation of the virtues' acquirer in receiving and exemplifying them. Since God's help in someone's having a trait doesn't preclude its being a virtue, Christian and theistic virtues can be modes of human agency; that is, they are modes of humans doing things, and doing them well. In making freedom one of the poles of one of his polarities of selfhood, ${ }^{23}$ Kierkegaard acknowledges and incorporates this basic conceptual point about virtues.

It may thus seem to follow that we acquire in God's eyes a degree of merit for our spiritual qualities proportionate to our agentic contribution to their formation and ongoing expression in our lives. Kierkegaard denies this. He imagines two people. One bears in mind for seventy years the love of God. He is faithful and single-minded in his desire for eternity. The other goes on year after year without a thought of God's love. Kierkegaard says that these two people are absolutely equally loved by God. ${ }^{24}$ In a Christian virtue ethics our virtues are utterly irrelevant to our moral standing before God. In theological terms, we might say that they are irrelevant to our justification. This is not to say that they are irrelevant to our eternal happiness; after all, they are modes of personal appropriation of God's love, and that is highly relevant to our eternal happiness. God loves you just as much as he loves Mother Teresa, but if you don't love him in return you won't have eternal happiness in God's love.

\section{Virtues as "Habits"}

Aristotle famously describes virtue acquisition as "habituation" (ethizesthai) in good actions, and the standard English translation of Aquinas's works renders the Latin "habitus" with "habit." These practices have led some people to speak of virtues as habits. But the word "habit" pretty strongly suggests automaticity of action (or better, of mere behavior), and this is a wrong suggestion for virtues, which are paradigmatically exemplified in actions performed with intelligent attention, with agency fully engaged. Aristotle's word comes from a word for custom, so that a possibly less misleading translation of hexis (the psychological result of the process of ethizesthai) might have it that we become virtuous by becoming accustomed to performing actions in a certain spirit. We become accustomed to thinking and feeling in ways characteristic of the virtues and to being personally engaged in what we do. And similarly, "habitus" suggests not automaticity, but full agentic engagement in its expressions. Walsh points out that a dimension of Kierkegaard's use of "earnestness" is the suggestion of full agentic engagement, and she seems to suggest that

${ }^{23}$ See Kierkegaard, Sickness unto Death, 13.

${ }^{24}$ See Kierkegaard, Without Authority, 165. 
because Kierkegaard thinks of the spiritual quality of patience as earnest, and virtues are habits, he must not think of patience as a virtue:

Patience is seen first of all as the quality that is needed to gain one's soul, which is possessed by every human being eternally but must be gained temporally by giving up the world for the eternal. To do that, however, one must develop and grow in patience through the "quiet but unflagging activity" 25 of repetition in the daily practice of patience not as a habit but in earnestness so as not only to gain but also to preserve one's soul in the ongoing struggle with oneself, the eternal, and God, who is patience itself. ${ }^{26}$

This description of acquiring the spiritual quality of patience is perfectly in line with a classical understanding of virtue acquisition. We develop virtues and grow in them by repeated unflagging activity in the practice of them. The repeated activity leaves behind a dispositional trace on our thinking, feeling, and acting that is our readiness to function virtuously; but the virtues' most characteristic expression is in moments when we are earnestly living or "existing" in them. This is not to deny that our virtues affect and presuppose, in various ways, our auto-pilot behaviors; it is just to say that in their most paradigmatic expressions we are fully engaged as agents.

\section{The Opposite of Sin Is Not Virtue, but Faith}

The following passage in The Sickness unto Death is "perhaps the most important reason why Kierkegaard should not be considered to be a virtue ethicist": ${ }^{\prime 7}$

Very often ... it is overlooked that the opposite of sin is by no means virtue. In part, this is a pagan view, which is satisfied with a merely human criterion and simply does not know what sin is, that all sin is before God. No, the opposite of $\sin$ is faith, as it says in Romans 14:23: "whatever does not proceed from faith is sin." And this is one of the most decisive definitions for all Christianity - that the opposite of $\sin$ is not virtue but faith. ${ }^{28}$

This is indeed a difficult passage to interpret on the assumption that Kierkegaard is sympathetic to reading the Christian life in virtue terms. Let's approach the passage by examining the crucial terms "virtue," "faith," and "opposite":

"Virtue": Walsh notes that some pro-virtue Kierkegaard interpreters read the passage as about pagan virtue, and not about the Christian virtues. After all, faith has been treated as a virtue in large swaths of the Christian tradition. One of the theses of this paper is that the Christian

\footnotetext{
${ }^{25}$ Kierkegaard, Eighteen Upbuilding Discourses 169-171, 187, 199; cf. Concept of Anxiety 149-151, 210.

${ }^{26}$ Walsh, Kierkegaard and Religion, 90.

${ }^{27}$ Walsh, Kierkegaard and Religion, 96.

${ }^{28}$ Kierkegaard, Sickness unto Death, 82. I'm grateful to Mark Murphy and an anonymous reviewer for Faith and Philosophy for their dissatisfaction with my interpretation of this passage in an earlier draft of this paper.
} 
virtues are different traits from the pagan ones, even when they go by the same name (say, "courage" or "justice"). Faith is absent from all the pagan lists that I'm familiar with. Perhaps Anti-Climacus is saying, "the opposite of $\sin$ is not what the pagans call virtue, but faith." He does say that the view that virtue is the opposite of sin is "in part" a pagan view. Another of the theses of this paper is that the Christian virtues are not perfections in the absolute sense (that is, excellences than which there is no greater of their kind). A person's having Christian patience, for example, is compatible with her patience being less than perfect. So the other "part" of the explanation why sin is the opposite of faith rather than virtue might be that even Christian virtue doesn't eliminate sin altogether. This would be compatible with Kierkegaard's work being largely for the purpose of upbuilding his reader in the Christian virtues.

"Faith": But our reading of "virtue" raises the question of what Anti-Climacus means by "faith." The passage that he quotes in support of his claim that the opposite of sin is not virtue but faith is Romans 14.23, of which the whole verse is, "But those who have doubts are condemned if they eat, because they do not act from faith; for whatever does not proceed from faith is sin." Paul is addressing the problem of whether to eat things that are prohibited to Jews and has said that all foods are clean, but people should consult their consciences about the matter. If you have misgivings about eating pork (say), it will be sinful for you to eat it, even though it's not generally sinful; but if you have a firm conviction ("faith," pistis) that it is okay, then it is okay. Thus what does not proceed from faith (that is, Christian conviction that it is okay to eat) is sin. "Faith" in the narrow sense of Paul's warning (really just heartfelt conviction that all foods are clean in the new order) is pretty obviously not a virtue. But Anti-Climacus, in a bold exegetical step, takes the text to mean or imply that "Faith is: that the self in being itself and in willing to be itself rests transparently in God." 29 Such faith is implicit joyful submission and trust in God ("resting"), a willingness to be exactly the self that God created one to be, including an unqualified willingness to be "seen" by God ("transparency"). But surely, by this definition, faith is a virtue. It is an excellent formation of the human self, and that is a perfectly good description of virtue.

Arguably, faith in this sense is a fundamental presupposition of all other Christian virtues, for example, of Christian gratitude, humility, compassion, forgivingness, hope, patience, and so forth. Unless "the self in being itself and in willing to be itself rests transparently in God," ${ }^{30}$ none of these other traits would be Christian virtues. If so, maybe Anti-Climacus thinks that faith should not be included among the virtues because it is too fundamental: it is not a virtue, but a presupposition of all genuine

\footnotetext{
${ }^{29}$ Kierkegaard, Sickness unto Death, 82; notice that this is the sentence immediately preceding the passage about virtue that we are discussing

${ }^{30}$ Kierkegaard, Sickness unto Death, 82.
} 
virtues. If this is his thinking, it seems to me not to be a very good reason for denying that faith is a virtue.

Despair, in any of its many variants, is a bad formation of the self. But despair is $\sin .{ }^{31}$ The definition of faith is symmetrical with the definition of despair (sin). The formula for despair is: in despair not to will to be oneself..$^{32}$ The formula for faith is "that the self in being itself and in willing to be itself rests transparently in God." 33 This is why faith is the opposite (the absence and good counterpart) of sin. As a counterpart of a bad formation of the self, faith would seem to be an excellent formation of the self. And it seems to me a reason for finding it odd to imply that faith is not a virtue.

"Opposite": Let's say that the opposite of sin is either the absence of sin or the good that is the counterpart of sin (as corrupt and evil), or both. We've noted that, as defined in The Sickness unto Death, both sin and faith are qualities or states of a self and are therefore traits (rather than actions or discrete events). Perfect faith is, then, the opposite of sin in both possible senses of "opposite." So the person with perfect faith no longer has the trait of despair/sin. But the person or self is more than his traits, because he is historical. He has a past, and his past is full of sin, even if he currently has faith in the sense of resting transparently in God. Resting transparently in God will not remove past sin from his self. So if we take the "opposite" of sin to be the absence of sin, then faith in a different sense from resting transparently in God will be needed to address it. Past sin cannot be removed, but it can be forgiven, and one of the many senses of "faith" in Kierkegaard's writings is belief in the atoning work of Christ. ${ }^{34}$ Here no virtue will bring about forgiveness; only Christ's atonement will do it. But faith in this sense is an assurance that past sins are forgiven.

\section{Virtue Ethics and Character Ethics}

Walsh denies that Kierkegaard is a virtue ethicist and says it would be more accurate to call him a character ethicist. ${ }^{35}$ She finds herself in need of a class-term for what the pro-virtue interpreters of Kierkegaard call virtues, and she settles on "spiritual qualities." But Kierkegaard uses the phrase "spiritual qualities" even less than he uses "virtues" (in fact, I think, not at all). It seems that he doesn't have an established general term, used in the plural, for the specific virtues or spiritual qualities that he so often explores poetically and conceptually. He does, however, have a number of global singular terms for personal formation or good formation: "inwardness," "subjectivity," "earnestness," "self," "personality," and "character." It is also true that increasingly starting around 1846 he speaks of character as the goal of ethical and spiritual upbringing and upbuilding.

\footnotetext{
${ }^{31}$ Kierkegaard, Sickness unto Death, 77.

${ }^{32}$ See Kierkegaard, Sickness unto Death, 13.

${ }^{33}$ Kierkegaard, Sickness unto Death, 82.

${ }^{34}$ See Kierkegaard, Philosophical Fragments.

${ }^{35}$ Walsh, Kierkegaard and Religion, 15, 107, 177.
} 
Almost all contemporary virtue ethicists would call themselves character ethicists, thus finding puzzling Walsh's proposal that Kierkegaard is "a character ethicist rather than a virtue ethicist." ${ }^{36}$ They would understand "character" as a general global term for that of which the virtues and vices are the more specific traits, features, or qualities. "Good character" or "virtuous character" would be a summary term for the virtues. So the question comes up, what does she think the difference is between virtue ethics and character ethics? In a footnote she refers the reader to Joel Kupperman's Character. Let's look at Kupperman's argument:

To approach ethics in terms of virtue is . . a step in the direction of approaching ethics in terms of character. The first step, virtue ethics, has advantages but also the disadvantages of a compartmentalized approach to moral judgment. It works well in simple and straightforward cases but not in ones in which considerations of different kinds conflict. ${ }^{37}$

Virtue ethics "works well" - for what? What is it supposed to accomplish? He thinks of virtue ethics as an "approach to moral judgment." So it's supposed to yield moral judgments. Judgments about what? Presumably, about what to do in a given circumstance, or how to evaluate an action already taken (in a circumstance). Kupperman seems to be saying that, given an action or opportunity for action, starting from a virtue concept (say, courage) with the purpose of figuring out what to do, or figuring out whether something already done was the right thing to do, will yield a reliable judgment in circumstances where only that virtue concept is relevant-for example, where the only question is, "Does courage require this action?" If courage does require this action and courage is the only relevant virtue, we can conclude that this action should be taken. But Kupperman thinks virtue ethics won't work so well where more than one kind of consideration needs attention. What if the situation forces a choice between courageously joining the resistance and compassionately staying home with your ailing mother? To obtain a correct judgment in this case it won't do to ask, "Does courage require this action?" or "Does compassion require this action?," because both virtues have appeal in the circumstance. One needs to ask, instead, "What does good character (which presumably includes both courage and compassion) require?" Two points:

One is that Kierkegaard's interest in character or qualities of character is not that of Kupperman's "approaching ethics in terms of character." When Kierkegaard thinks about character and its qualities, he isn't trying to come to a judgment about whether an action is right or wrong, or offering an account of how we come to such judgments. In contrast, his discourses and deliberations highlight character and its traits in the interest of building up character and its traits in himself and his reader. He is not engaging in what modern philosophers call "ethical theory," and

\footnotetext{
${ }^{36}$ Walsh, Kierkegaard and Religion, 15, italics added.

${ }^{37}$ Kupperman, Character, 112.
} 
he is decidedly not a "virtue ethicist" in the way that Rosalind Hursthouse or Michael Slote or Gary Watson is. Kierkegaard's deployment of reflection about character traits is much more like the ancient character ethics of Socrates, Plato, Aristotle, and the Hellenistic philosophers than it is like the kind that arose toward the end of the twentieth century and of which Kupperman's argument for character ethics and against virtue ethics seems to be a variant. So the first point is that Kupperman's "character ethics" is irrelevant to the interpretation of Kierkegaard. Like the classical virtue ethicists, Kierkegaard makes conceptual points about the interconnections and purposes of the virtues and normatively defends the superiority of a life of virtue over a purely "esthetic" life and to that extent is doing "ethical theory." But all such reflection is subordinate to the larger task of personal transformation.

The second point is that Kupperman's distinction between virtue ethics and character ethics is bogus in itself. The doctrine of the "unity" of the virtues may be controversial in its details but not as the thesis that the virtues come in clusters of mutually supportive traits and that to be a person of character is to have an array of virtues that make up one's character, bound together by a vision of what human life is about and what is good; and that the person of character is thus equipped with some way or ways of deciding what to do in situations that seem to call for more than one virtue. (All, or almost all, situations call for more than one virtue.) For Aristotle, the virtue that allows for virtuous action in complex situations - and indeed, in all situations - is practical wisdom. It's hard to imagine a virtue ethicist, contemporary or ancient, who would employ the "compartmentalized approach to moral judgment" that Kupperman describes. So the second point is that no virtue ethics (in the modern sense) functions in the abstract way that Kupperman imagines. His conception of virtue ethics is artificial, neglecting the commitment of virtue ethics to the interconnectivity of the virtues.

Returning to Walsh,

Kierkegaard's primary concern is not with becoming a virtuous person but with becoming a concrete personality, single individual, and person of character through the formation of an authentic self via a relation to God. It would therefore be more appropriate to classify him as a character ethicist than a virtue ethicist..$^{38}$

Like Kupperman, Walsh thinks of virtue ethics as fragmentary in contrast with character ethics, which she thinks of as holistic, focusing "on a sense of self as that which unifies life and gives it meaning." ${ }^{39}$ But this contrast fails to notice that each of the virtues that Kierkegaard explores is a property of the self, and furthermore, each of the virtues, in its own way, involves a sense of the self. All the virtues involve self-understanding;

${ }^{38}$ Walsh, Kierkegaard and Religion, 107.

${ }^{39}$ Walsh, Kierkegaard and Religion, 219n187. 
all deep self-understanding involves issues addressed by the virtues; all correct self-understanding is virtuous by relation to some virtue or other; each virtue contributes to an overall picture of the self, an overall self-understanding. To love your neighbor as yourself, you have to have a distinct understanding of yourself, as Kierkegaard makes clear in Works of Love; similarly for God to be the "middle term" between self and neighbor. If faith presupposes infinite resignation, as Johannes de Silentio proposes in Fear and Trembling, then faith must involve a sense of oneself as detached, in a certain way, from worldly expectations; and if faith involves an ongoing personal dependency on its historical object, as Johannes Climacus proposes in Philosophical Fragments, it necessarily involves a sense of oneself as so dependent. Humility entails a sense of the limitation of one's own powers; contrition is a sense of one's own moral corruption; forgivingness involves a sense of having been forgiven, and forgiveness often involves knowledge of oneself as victim; gratitude involves a sense of having been given a gift; and so forth, plausibly, for all the virtues. One might even argue that the theistic and Christian virtues, in Kierkegaard's understanding of them, are dimensions of the synthesis of the finite and infinite, the temporal and the eternal, of freedom and necessity, as Anti-Climacus defines the self in The Sickness Unto Death. Whether that reading can be worked out in detail remains to be seen, but I submit that Walsh's own description of the virtue of patience, quoted above, suggests such a reading.

But let's not despise the fragmentary, either. Johannes Climacus's railings against the Hegelian System suggest that for finite human beings there's something to be said for philosophical fragments, for serving up one's edification in bite-sized bits, to prevent choking and promote chewing and digesting. Usually, in both his discourses and his pseudonymous works, Kierkegaard doesn't speak of character in the abstract, but focuses on one dimension or another of Christian character-love, faith, bold confidence, courage, humility, hope, patience, and so on, and usually even more specifically within a context. For example, in "To Need God is a Human Being's Highest Perfection," 40 Kierkegaard arguably treats the virtue of humility, but even more specifically in its application to self-knowledge. His complaint about the System was existential indigestion. Like reading the System for self-improvement, a character ethics that wasn't a virtue ethics might be like trying to swallow the whole farm at once. Kierkegaard's character ethics is existentially nutritious, in part because it is a virtue ethics, and one that serves up the distinct virtues in all their rich detail.

\section{Conclusion}

It is possible that Kierkegaard avoids or minimizes commendatory use of the word "virtue" because of just the associations that Walsh notes: with

\footnotetext{
${ }^{40}$ Kierkegaard, Upbuilding Discourses, 292-326.
} 
merit, with independence of God, with "habit," with complete perfection in this life, with unhealthy self-preoccupation. I leave open the question to what extent these associations are actually justified, even with respect to "pagan" virtues. But if we realize that such associations aren't necessary and insist on attributing only Christianity-compatible properties to virtues, and if we think of virtue ethics as an exploratory, reflective, and "poetic" strategy for inculcating wisdom, for upbuilding ourselves and our interlocutors in Christian character, we have no reason not to associate Kierkegaard with "virtue ethics." The association could help us conceive virtue ethics as an enterprise one of whose chief purposes is to make us wise and good. Historically, the notion of a virtue is ample enough to include the "spiritual qualities" that Christians have sought to form in members of the church by the grace of God in response to the person and work of Jesus Christ. Furthermore, if Christian philosophers wish to be in dialogue with philosophers outside the church, the word "virtue" seems to offer a natural bridge between Christian ethics and the character ethics of non-religious as well as other religious traditions. ${ }^{41}$

Baylor University

\section{References}

Aristotle. 1980. Nicomachean Ethics. Translated by David Ross and edited and revised by J. L. Ackrill and J. O. Urmson (Oxford University Press).

Hadot, Pierre. 2002. What is Ancient Philosophy? Translated by Michael Chase (Belknap Press).

Hursthouse, Rosalind. 1999. On Virtue Ethics (Oxford University Press).

Kierkegaard, Søren. 1967-1978. Søren Kierkegaard's Journals and Papers, 7 vols. Edited and translated by Howard V. Hong and Edna H. Hong, assisted by Gregor Malantschuk (Indiana University Press).

Kierkegaard, Søren. 1980. The Concept of Anxiety. Edited and translated by Reidar Thomte in collaboration with Albert B. Anderson (Princeton University Press).

Kierkegaard, Søren. 1980. The Sickness unto Death. Edited and translated by Howard V. Hong and Edna Hong (Princeton University Press).

Kierkegaard, Søren. 1983. Fear and Trembling and Repetition. Edited and translated by Howard V. Hong and Edna Hong (Princeton University Press).

Kierkegaard, Søren. 1985. Philosophical Fragments. Edited and translated by Howard Hong (Princeton University Press).

Kierkegaard, Søren. 1990. Eighteen Upbuilding Discourses. Edited and translated by Howard H. Hong and Edna H. Hong (Princeton University Press).

\footnotetext{
${ }^{41}$ Mark Murphy and two anonymous reviewers for Faith and Philosophy offered helpful suggestions for revision of this paper.
} 
Kierkegaard, Søren. 1992. Concluding Unscientific Postscript to "Philosophical Fragments," 2 vols. Edited and translated by Howard V. Hong and Edna H. Hong (Princeton University Press). https://doi.org/10.1515/9781400846993

Kierkegaard, Søren. 1995. Works of Love. Edited and translated by Howard V. Hong and Edna H. Hong (Princeton University Press).

Kierkegaard, Søren. 1997. Without Authority. Edited and translated by Howard V. Hong and Edna H. Hong (Princeton University Press).

Kierkegaard, Søren. 1993. Upbuilding Discourses in Various Spirits. Edited and translated by Howard V. Hong and Edna H. Hong (Princeton University Press).

Kupperman, Joel. 1991. Character (Oxford University Press).

Roberts, Robert. 2013. Emotions in the Moral Life (Cambridge University Press). https://doi.org/10.1017/CBO9781139061469

Roberts, Robert. 2017. “Varieties of Virtue Ethics." In Varieties of Virtue Ethics, edited by David Carr, James Arthur, and Kristján Kristjánsson (Palgrave Macmillan), 17-34. https://doi.org/10.1057/978-1-137-59177-7_2

Slote, Michael. 2001. Morals from Motives (Oxford University Press). https://doi.org/10.1093/0195138376.001.0001

Walsh, Sylvia. 2017. Kierkegaard and Religion (Cambridge University Press).

Watson, Gary. 1993. "The Primacy of Character." In Identity, Character, and Morality, edited by Owen Flanagan and Amélie Rorty (MIT Press), 449-469. 